\title{
RELEVANSI DAN KONTINUITAS PEMIKIRAN ISLAM KLASIK DALAM INTELEKTUALISME ISLAM MELAYU NUSANTARA
}

\author{
Ris'an Rusli \\ Universitas Islam Negeri Raden Fatah Palembang \\ Jl. Prof. K.H. Zainal Abidin Fikri Palembang, Sumatera Selatan, Indonesia \\ E-mail: risanrusli_uin@radenfatah.ac.id \\ Yanto \\ Universitas Islam Negeri Raden Fatah Palembang \\ Jl. Prof. K.H. Zainal Abidin Fikri Palembang, Sumatera Selatan, Indonesia \\ Email: yanto_uin@radenfatah.ac.id
}

\begin{abstract}
This study aims to determine the relevance and continuity of classical Islamic thought in Nusantara Malay Islamic intellectualism, expected to be useful in adding to the treasures of the study of history and intellectual thought while also contributing to the preservation of scientific traditions in Indonesia. This study uses a type of qualitative research with a library research model with a historical approach. The data collection techniques in the study are heuristic techniques, verification, interpretation, and historiography. The results of this study conclude that first, the process of the intellectual tradition of Malay Archipelago Islam is inseparable from the process of transmission and diffusion of Islamic teachings and ideas always involving a kind of "intellectual networks", both those formed among ulama and intellectuals as a whole. Second, the relevance of classical Islamic thought in Nusantara Malay Islamic intellectualism can be seen in the existence of the two largest organizations in Indonesia, the Nahdlatul Ulama (NU) whose intellectualism led to the Jabariah sect and Muhammadiyah whose intellectualism was directed towards Muta'zilah. Third, the continuity of classical Islamic thought in Nusantara Malay Islamic intellectualism gave rise to Malay-archipelago modernist thinkers closer to the Mu'tazilah's historical establishment than to the traditionalist historical stance.
\end{abstract}

Keywords:

Relevance; Continuity; Classical Islam; Intellectualism ;Malay.

\begin{abstract}
Abstrak
Penelitian ini bertujuan untuk mengetahui relevansi dan kontinuitas pemikiran islam klasik dalam intelektualisme Islam Melayu Nusantara, diharapkan akan bermanfaat dalam menambah khazanah studi sejarah dan pemikiran intelektual sekaligus memberikan kontribusi bagi pelestarian tradisi keilmuan di Indonesia. Penelitian ini menggunakan jenis penelitian kualitatif dengan model penelitian pustaka (library research) dengan pendekatan historis. Adapun teknik pengumpulan data dalam penelitian adalah teknik heuristik, verifikasi, interpretasi, dan historisografi. Hasil penelitian ini menyimpulkan bahwa pertama, proses tradisi intelektual Islam Melayu Nusantara tidak terlepas dari proses transmisi dan difusi ajaran dan gagasan Islam selalu melibatkan semacam "jaringan intelektual" (intellectual networks), baik yang terbentuk di kalangan ulama maupun intelektual secara keseluruhan. Kedua, relevansi pemikiran Islam klasik dalam intelektualisme Islam Melayu Nusantara dapat dilihat dalam eksisnya dua organisasi terbesar di Indonesia yaitu Nahdlatul Ulama (NU) yang dalam intelektualismenya mengarah pada aliran Jabariah serta Muhammadiyah yang intelektualismenya mengarah pada Muta'zilah. Ketiga, kontinuitas pemikiran Islam klasik dalam intelektualisme Islam Melayu Nusantara memunculkan pemikir modernis Melayu-Nusantara lebih dekat dengan pendirian historis Mu'tazilah ketimbang dengan pendirian historis tradisionalis.
\end{abstract}

Kata Kunci:

Relevansi; Kontinuitas; Islam Klasik; Intelektualisme; Melayu.

DOI: $10.15575 /$ jw.v3i2.3582

Received: September 2018 ; Accepted: November 2018; Published: December 2018 


\section{A. PENDAHULUAN}

Realitas yang tergambar dalam pemikiran pada dasarnya dapat dikelompokkan ke dalam dua golongan yaitu golongan realitas teoritik dan empirik. Pemikiran yang tergambar dalam dunia ide seseorang bisa dikatakan sebagai teoritik semata, berbeda halnya dengan suatu ide yang telah terlaksana atau berada di dalam dunia nyata dapat dikatakan sebagai empirik. Kedua pola tersebut tidak harus terpisah namun saling berpengaruh aktif dalam pemikiran seseorang. Munculnya amal pemikiran seseorang berawal dari keprihatinan pada realita teoritis tersebut yang akan berdampak langsung pada realita empirik. Realita yang bersifat teoritik pada dasarnya merupakan hal-hal yang tergambar dalam ide-ide yang diberikan atau pola pikir para ulama tersebut. Namun berbeda halnya dengan realita yang bersifat empirik. Dimana realita yang bersifat empirik merupakan realita yang sudah tergambar jelas di depan mata atau yang sudah ada. Sehingga hal ini dapat dilihat, dirasakan oleh para penikmatnya ${ }^{1}$.

Sejarah membuktikan bahwa permasalahan pemikiran keagamaan sebagaimana penjelasan di atas banyak intelektual muslim memiliki keprihatinan yang serupa yaitu bagaimana agama bisa dipahami dengan benar. Pemahaman ini melahirkan berbagai macam aliran-aliran dalam Islam. Dari keprihatinan di atas dan atas pertanyaan-pertanyaan inilah para pemikir Islam ketika itu merasa tertantang merumuskan jawaban yang benar dengan ajaran-ajaran Islam yang sahih. Masing-masing jawaban tumbuh sebagai aliran pemikiran yang berdiri sendiri, hal ini bukan hanya sebatas di kota Haramain saja namun merambah ke penjuru dunia termasuk Indonesia. Pemikiran-pemikiran yang berkembang di Indonesia, yang pada dasarnya berasal dari hasil intelektual ulama klasik diantaranya ulama Mu'tazilah serta Jabariah.

Intelektual ulama Indonesia atau bisa dikatakan ulama Melayu Nusantara berawal dari abad ke 7, dimana banyak ulama Indonesia yang belajar dan menuntut ilmu ke kota Haramain

1 Budhy Munawar-Rachman, Kontekstualisasi Doktrin Islam dalam Sejarah (Jakarta: Paramadina, 1995), 123-25.
(Mekkah dan Madinah). Kota-kota tersebut merupakan pusat agama Islam atau kota kelahiran agama Islam. buha hasil pembelajaran ulam-ulama tersebut akan melahirkan karya-karya yang mendunia terutama menjadi referensi ulama modern ini. Hal ini menjadi dasar pemikiran ulama-ulama pada saat ini.

Perkembangan kedua pemikiran tersebut merambah ke Indonesia melalui jalur pewarisan intelektual dari kota asalnya Haramain yaitu kota Mekkah dan Madinah. Pemikiran-pemikiran ulama tersebut akan menghasilkan dua organisasi besar di Indonesia yaitu Muhammadiyah yang bersifat modern dalam pendidikannya atau mendekati Mu'tazilah dan Nahdlatul Ulama (NU) dalam hal ini mendekati pemikiran Jabariah $^{2}$.

Budaya paternalistik yang berkembang dan atau dikembangkan di dunia MelayuNusantara (Indonesia) menyebabkan intelektualisme menjadi agenda yang tidak kunjung usai. Alasannya, pemikiran yang diterjemahkan dalam watak budaya politik, mempengaruhi persepsi serta praktik pola pikir bernegara di Indonesia. Selama ini masyarakat Melayu-Nusantara telah terbiasa hidup dengan utopia. Itulah yang menyebabkan masa depan yang tidak pasti. Akibatnya, rakyat menjadi korban dan selalu dibayangi mimpi-mimpi semua tentang kesejahteraan yang sebenarnya hanyalah ilusi yang diciptakan para aktor saat ini.

Tentu kondisi demikian tidak ingin terusmenerus terjadi. Di sinilah perlu menggali khazanah intelektual Islam klasik. Dalam perjalanan bangsa Indonesia (MelayuNusantara) sejak berabad-abad yang lalu menunjukkan adanya pengaruh signifikan antara pemikiran Islam klasik dengan intelektual Islam Melayu Nusantara. Salah satunya adanya relevansi dan kontinuitas yang turut mewujudkan dan membentuk jati diri identitas Melayu-Nusantara.

2 Susiknan Azhari, "Karakteristik Hubungan Muhammadiyah dan NU dalam Menggunakan Hisab dan Rukyat," Al-Jami'ah: Journal of Islamic Studies 44 , no. 2 (2006): 453-86. 
Karenanya, pengaruh pemikiran Islam klasik dalam intelektual Islam Melayu sebelumnya pasti tanpa pada semua pemikiran (wacana). Namun, secara ilmiah tetap perlu dipertanyakan apa argumen-argumen yang melandasi relevansi dan kontinuitas pemikiran Islam klasik itu, seberapa tepat argumen-argumen tersebut, apakah hal itu dapat diterima secara ilmiah atau tidak.

Menginjak pada pernyataan-pernyataan di atas, maka permasalahannya dalam penelitian ini adalah 1). Bagaimana relevansi pemikiran Islam klasik dalam intelektualisme Islam Melayu Nusantara?; dan 2). Bagaimana kontinuitas pemikiran Islam klasik dalam intelektualisme Islam Melayu Nusantara ?. Penelitian ini bertujuan untuk mengetahui relevansi dan kontinuitas pemikiran Islam klasik dalam intelektualisme Islam Melayu Nusantara. Dengan demikian penelitian diharapkan akan bermanfaat dalam menambah khazanah studi sejarah dan pemikiran intelektual sekaligus memberikan kontribusi bagi pelestarian tradisi keilmuan di Indonesia. Penelitian ini menggunkan jenis penelitian kualitatif dengan model penelitian pustaka (library reserch) dengan menelaah secara teliti berbagai literatur-literatur yang relevan. Pendekatan penelitian dengan menggunakan konsep keilmuan, yaitu: historis. Sedangkan sumber data adalah primer dan skunder. Adapun teknik pengumpulan data dalam penelitian adalah teknik heuristik, verifikasi, interpretasi, dan historisografi.

\section{B. HASIL DAN PEMBAHASAN}

\section{Relevansi Intelektual Islam Klasik dengan Ulama Melayu Nusantara}

Kejayaan Nusantara tersohor di mana-mana sehingga akan menarik para pedagang di seluruh dunia untuk memperjual belikan dagangannya. Mulai dari India yang berdagang di kawasan Nusantara pada abad ke 7 Masehi. Kaum pedagang seantero dunia berdagang dan juga bermukim di Nusantara atau yang kita kenal pada saat ini adalah Indonesia, selain menjajakan dagangan, mereka juga lambat laun mengajarkan keyakinan mereka pada penduduk asli daerah tersebut. Selain sebagai tempat berdagang, Indonesia atau Nusantara juga dikenal sebagai pusat rempah-rempah seperti wilayah Kalimantan dengan buah palaya, Sumatera dengan kopi, lada dan lain sebagainya. Sehingga banyak bangsa Eropa lainnya yang datang ke Nusantara juga. Tidak ketinggalan pula bangsa Arab yang berdagang di Nusantara atau Indonesia.

Melihat kondisi itu, tidak heran rasanya jika bangsa Indonesia dikenal di dunia dan bangsa ini tidak terlepas dari pengaruh dunia terutama pada intelektualnya, hal ini diakibatkan dari kejayaan bangsa Indonesia itu sendiri yang berperan aktif dalam jalur perdaganga dunia. Mereka-mereka yang berdagang tersebut ada yang membawa misi agama seperti Arab dengan agama Islamnya yang kita lihat penduduk Indonesia saat ini, ataupun negara Barat atau Eropa dengan misi Kristen-nya yang dapat dilihat di bagian timur Indonesia.

Banyaknya penduduk Indonesia yang menimbah ilmu di negara Haramain atau Kota Mekkah dan Madinah tersebut hingga menghasilkan banyak corak pemikiran di Indonesia. Pendekatan yang dilakukan oleh Islam diantaranya Islam tidak menanamkan sistem kasta dalam sosial yang selama ini ada di Indonesia. Melalui jalur pernikahan, dan bahkan menjadi penasihat raja-raja Nusantara dikala itu ${ }^{3}$. Berbagai teori yang menyatakan masuknya Islam di Indonesia yang secara keseluruhan mempunyai pendukung dan kekurangan masing-masing, namun hal yang menguatkan adalah bahwa Islam di Indonesia merupakan Islam yang Rahmatan Lil Alamanin (rahmat bagi alam semesta). Dengan kondisi masyarakat yang beragam dalam tata cara, bahasa, adat dan kebudayaan Islam tetap tumbuh dan berkembang dengan sendirinya di Indonesia.

Prihatin terhadap hal di atas, memaksa para Ilmuwan untuk melahirkan teori-teori

\footnotetext{
${ }^{3}$ M Atho Mudzhar, "Masyarakat Indonesia Baru dalam Perspektif Global,” Mukaddimah 5, no. 8 (1999).
} 
dalam menjawab permasalahan di atas, dengan landasan dan argumen yang dapat dipertanggungjawabkan. Mulai dari kedatangan Islam di Indonesia berasal dari India, ada juga yang mengatakan bahwa Islam di Indonesia berasal dari Arab langsung, bahkan ada yang menyatakan bahwa Islam di Indonesia berasal dari Cina, hal-hal tersebut memiliki alasan dan argumen masing-masing. Namun sejarah membuktikan bahwa sebelum Islam datang ke Indonesia bahwa negara ini merupakan pusat perdangangan dunia atau bisa dikatakan tempat persinggahan para pedagang dari belahan dunia termasuk Arab sendiri ${ }^{4}$. Pedagang-pedagang tersebut singgah dan bermukim di Nusantara bahkan ada yang menetap, maka tidak menutup kemungkinan bahwa para pedagang tersebut mengajarkan keyakinannya yang ia bawa dari negara asalnya.

Perbedaan-perbedaan yang terjadi di kalangan intelektual mengenai Islam di Indonesia atau islamisasi Islam di Indonesia maka perlu adanya sintesis terhadap apa yang berkembang tersebut. Hal ini dilakukan berdasarkan waktuwaktu yang ada atau fase dalam periodesasi masuknya Islam di Indonesia, dari berbagai teori dan pemikiran para intelektual di atas namun belum ada yang membicarakan di pulau mana Islam itu masuk dan penyebarannya dari pulau ke pulau lainnya di Indonesia. Secara nyata bahwa bangsa Indonesia atau kepulauan nusantara terdiri dari pulau-pulau besar dan kecil. Pulau besar yang diawali dari Pulau Kalimantan, Sumatera, Jawa, Sulawesi, dan Papua, bahkan banyak lagi pulau kecilnya dan setiap pulau pasti ada yang beragama Islam, dalam catatan sejarah teori tersebut hanya menceritakan Islam yang ada di Pulau Sumatera yaitu diawali dari Aceh yang mana dimulai dari kerajaan Samudra Pasai, dan juga yang berasal dari Pulau Jawa yaitu Kerajaan Demak, dua kerajaan tersebut memiliki andil

\footnotetext{
${ }^{4}$ Muhammad Iqbal, "Akar Tradisi Politik Sunni di Indonesia Pada Masa Kerajaan Islam di Nusantara," ISLAMICA: Jurnal Studi Keislaman 6, no. 1 (2011): 5165.

${ }^{5}$ Hasan Ashari, Menguak Sejarah Mencari 'Ibrah: Risalah Sejarah Sosial-Intelektual Muslim Klasik (Bandung: Citapustaka Media, 2006), 144.
}

penting dalam penyebaran Islam di kawasan Indonesia ${ }^{5}$.

Apapun argumennya mengenai masuknya Islam di Indonesia pasti berdasarkan pada pembuktian-pembuktian sejarah yang didapatnya, baik itu berupa batu nisan, perkumpulan para Wali Songo, bahkan peninggalan lainnya, pada dasarnya orang yang berasal dari negara asalnya dan menetap serta berdagang di suatu negara berdasarkan jalur perdagangan yang digunakan dan pada masa itu ialah sungai dan lautan. Sehingga dapat disimpulkan perkembangan Islam di Indonesia ialah berawal dari pinggiran sungai dan pesisir pantai, namun akhir abad ke 13 ditemukan adanya jejak orang Islam pribumi.

Perdebatan tersebut tidak begitu saja berhenti pada perdebatan panjang Jabariah dan Qodariah, masalah penciptaan manusia tetap ramai dan dilengkapi juga oleh Mu'tazilah, Asy'ariyah, dan Maturidiyah. Perdebatan-perdebatan dalam aliran kalam ini awalnya tidak berbeda dengan pemahaman-pemahaman lainnya yang telah muncul terlebi dahulu. Berawal dari pemikiran kalam yang dikemukakan Mu'tazilah yang pada dasarnya hampir sama dengan pemikiran yang dikemukakan Qodariyah. Berbeda halnya dengan pemikiran yang diambil atau diikuti Asy'ariyah yang pada dasarnya lebih mendekati pada pemikiran yang dikemukakan oleh kaum Jabariah ${ }^{6}$.

Perdebatan tersebut juga merambah pada ulama-ulama Nusantara atau Indonesia, hal ini didasarkan atas ulama-ulama Nusantara atau Indonesia secara langsung belajar ke dua kota yang menjadi pusat pemikiran Islam tersebut yaitu kota Mekkah dan Madinah. Diantaranya Muhammad Natsir bisa dikatakan cenderung pada pemahaman Qodariyah. dalam pandangannya memandang bahwa manusia bebas berbuat aktif,

\footnotetext{
6 Oman Fathurahman, "Jaringan ulama: pembaharuan dan rekonsiliasi dalam tradisi intelektual islam di dunia Melayu-Indonesia," Studia Islamika 11, no. 2 (2004).
} 
kreatif dan dinamis, itu artinya manusia dapat menentukan apa yang ingin dia lakukan baik dan buruknya ${ }^{7}$. Pada dasarnya pemikiran tersebut merupakan masih dalam Sunnatullah (hukum alam) yang diciptakan Tuhan, serta berkaitan erat pula dengan sebab-sebab yang dilakukan manusia. Dan ini juga menunjukkan bahwa apa yang terjadi pada diri manusia bukan suatu takdir atau nasib yang telah ditentukan Tuhan semenjak awal. Tetapi semuanya terkait dengan usaha, ikhtiar dan perbuatan manusia.

Pemikiran yang dikemukakan Mu'tazilah lebih mendekati pada pemahaman yang dikemukakan oleh paham Qodariyah. Berbeda jauh dengan pemikiran Asy'ariyah yang pada dasarnya mengarah pada pemikiran yang dikemukakan oleh Jabariah. Hal tersebut merambah pada pemikiran-pemikiran yang terjadi di Indonesia, diantaranya yaitu Nahdlatul Ulama (NU) hal ini menunjukakan pola pikir keIslaman khas serta bernuansa Nusantara ${ }^{8}$. Nahdlatul Ulama (NU) pada dasarnya lebih melestarikan tradisi keislaman yang ada dan sudah berkembang di Nusantara. Dalam pembelajaran ulama-ulama Nusantara ke kota Mekkah dan Madinah maka secara langsung pemikirannya akan berpengarauh pada ulama-ulama Nahdlatul Ulama di Indonesia.

Proses tradisi intelektual ini tidak terlepas dari proses transmisi dan difusi pola pikir atau ide-ide yang terorganisir, hal ini merupakan salah satu segmen dari kaum intelektual secara keseluruhan. Yang disebut sebagai "jaringan ulama" adalah jalinan hubungan yang kompleks dan luas, yang terdapat baik yang terbentuk antar ulama sendiri maupun antara ulama dan murid-muridnya9 .

Upaya yang lain awal dilakukan adalah menyampaikan berbagai ajaran Islam melalui tradisi lisan. Namun, seiring dengan semakin meningkatnya jumlah masyarakat yang tertarik mempelajari Islam, segenap muncul akan kebutuhan teks-teks keagamaan yang diperlukan

7 AS Sunarto, "Paradigma Nahdlatul 'ulama Terhadap Modernisasi," Jurnal Sosiologi Islam 3, no. 2 (2013)

8 Oman Fathurrahman, Tradisi Intelektual Islam Melayu-Indonesia: Adaptasi dan Pembaharuan: Book dalam dakwah atau panduan dalam penyampaian makna Islam pada masyarakat. Suatu pemikiran tidak akan memiliki kekuatan atau daya gugah kearah perubahan kalau ia tidak menemukan saluran ekspresifnya. Salah medan pendewasaan kepastian dialog umat yang paling tepat adalah medium gagasan.

\section{Kontinuitas dan Perubahan Wacana Intelektual Islam di Dunia Melayu- Nusantara}

Muncul dan berkembangnya intelektual Islam di Indonesia berawal dari proses transmisi keIslaman, ide-ide keIslaman, dan bahkan pengembangan ilmu pengetahuan. Hal-hal semacam inilah yang membangkitkan para Ilmuwan Islam dalam mengembangkan dan menyebarluaskan pengetahuan yang didapatkannya, dan pada akhirnya akan terus berlanjut hingga saat ini. Hasil dari buah pikir ilmuwan Islam disalin dan dikaryakan menjadi karya-karya yang dirujuk pada ulama-ulama saat ini. Hubungan yang begitu kuat terhadap keilmuan Islam yang ada di kota Haramain maka akan semakin kuat pengaruhnya terhadap ulama-ulama Nusantara. Dalam hal ini hubungan antara guru dan santri akan begitu berperan aktif serta ada pengaruh yang signifikan.

Cara yang dilakukan dalam penyampaian pemikiran atau pandangan seorang guru yaitu dengan tradisi lisan, artinya bertemu langsung pada sang guru dalam konteks pembelajaran. Lambat laun dengan perkembangan zaman maka cara-cara seperti itu akan berubah pula. Hal ini terjadi diakibatkan dengan semakin bertambahnya jumlah masyarakat yang ternyata minat dan bakatnya merasa sangat ingin mempelajari agama Islam atau lebih mengenal agama Islam lebih lanjut. Dengan alasan mempermudah umat dalam mengenal ajarannya maka banyak akan diciptakan

Review Peter Riddell, Islam and the MalayIndonesian World (Singapore: Horizon, 2001).

9 Azyumardi Azra dan Oman Fathurrahman, Jaringan Ulama, ed. oleh Taufik Abdullah, 5 ed. (Jakarta: Ichtiar Baru van Hoeve, 2002). 
teks-teks karya ilmuwan muslim. Sumbersumber pengetahuan dibangkitkan dari intelektual ulama klasik sendiri. Hal ini menjadi dasar yang utama dalam mempermudah penyebaran agama Islam.

Lahirnya pandangan dan ide-ide yang cemerlang berdasarkan pada suatu pengalaman, pengalaman yang didapatkan biasanya bisa berasal dari peristiwa, bisa dari belajar dan sebagainya. Dalam konteks ini pengalaman yang diberikan oleh guru atau kesinambungan pemikiran. Maka dalam intelekutalnya ada keutamaan dalam pengembangan menuju arah perubahan dalam masyarakat tersebut baik dari pola pikirnya ataupun lainnya. Areal yang menjadi fokusnya atau pendewaan pemikiran adanya dialog sebagai ajang pertukaran pemikiran yang tepat dalam menjawab tantangan yang ada atau hal yang dibutuhkan umat.

Perlu dijelaskan di sini bahwa sejarah merupakan sebuah tradisi antara guru dan muridnya yang berlaku hingga saat ini berdasarkan dari sejarah yang ada. Dalam mempelajari sejarah dapat diketahui hal yang terjadi di masa lalu oleh intelektual masa kini. Inilah yang dinamakan hubungan yang berkelanjutan. Berdasarkan kerangka keragaman (diversity), perubahan (change), kesinambungan (continyuity), dan keterkaitan (relevansy) melalui dimensi waktu ${ }^{10}$. Dari sini, gagasan atau wacana keIslaman yang berkembang dalam pemikiran kontemporer Islam di dunia Melayu-Nusantara merupakan kesinambungan dari pemikiran Islam klasik, baik itu berupa tesis, antitesis, maupun sintesis.

Kemajuan pemikiran seseorang atau kekayaan intelektual dalam masyarakat yang dalam hal ini dapat mengungkapkannya berbentuk karya-karya di khalayak umum. Hal ini dapat dilacak melalui adanya kesinambungan antara figur intelektual dan konfigurasinya dalam pemahaman dan penerapan keilmuan yang ia dapatkan atau intelektualnya. Bisa diwujudkan dalam reaktualisasi lisan dan tulisan atau juga melalui bahasa yang digunakan ${ }^{11}$. Pandangan

10 Hartono Margono, “KH. Hasyim Asy'ari dan Nahdlatul Ulama: Perkembangan Awal dan Kontemporer," Jurnal Media Akademika 26, no. 3 (2011). pemikiran seseorang selalu didasari atas hal-hal yang bersifat kesinambungan antara guru dan santrinya maka hal ini dapat dikenal dengan sebutan sejarah keilmuan manusia atau sejarah intelektual manusia, dalam konteks berbudaya.

Melihat situasi sedemikian rumitnya, membuat hal ini tidak terus menerus berkembang. Artinya membutukan figurfigur intelektual yang kompeten dan bersifat klasik. Sejarah membuktikan bahwa bangsa Indonesia telah berabat silam lamanya membuktikan adanya kesinambungan intelektual dalam pemikiran yang diwariskan oleh Islam yang bersifat klasik terhadap pemahaman keilmuan ulama-ulama Melayu atau intelektualisme ulama-ulama Indonesia. Hal inilah yang membuktikan adanya relevansi dan kontinuitas intelektual ulama klasik dan intelektual ulama Melayu atau ulama Indonesia.

Intelektual Islam Melayu Nusantara tentu tidak terlepas dari konteks Islam dan Melayu. Memasuki abad ke 19 tradisi intelektual Islam di dunia Melayu mengalami penguatan pemikiran, terutama dalam karya-karya atau gagasan-gagasan. Budaya paternalistik yang berkembang dan atau dikembangkan di dunia Melayu-Nusantara (Indonesia) menyebabkan intelektualisme menjadi agenda yang tidak kunjung usai. Tentu kondisi demikian tidak ingin terusmenerus terjadi. Di sinilah perlu menggali khazanah intelektual Islam klasik.

Sejarah menunjukkan persoalan alQada' dan al-Qadr telah timbul atau ada di Malaka. Buku sejarah Melayu menggambarkan bahwa di tanah Melayu Malaka sedang mengalami perdebatan dalam masalah tersebut antara pendukung paham Jabariah dan Qadariyah. Menurut Jabariah, beranggapan bahwa nasib atau rezeki seseorang itu telah ditentukan sejak dahulu dan manusia tidak memiliki daya ikhtiar untuk mengubah kehendak Tuhan. Sebaliknya, paham Qadariyah mendukung kebe-

11 Badri Yatim, Sejarah Peradaban Islam Dirasah Islamiyah II (Jakarta: Raja Grafindo Persada, 2010), 23. 
basan ikhtiar manusia dengan alasan bahwa manusia bertanggungjawab terhadap perbuatannya sendiri. Persoalan ini begitu merumitkan sehingga menyebabkan ia terpaksa merujuk kepada para ulama di Pasai untuk mencari penyelesaiannya. Dalam kondisi demikian, paham Qadariyah mendapat serangan dan sampai pada pengkafiran kelompok paham Qadariyah, karena hampir semua ulama di Melayu memiliki paham Ahlus Sunnah wal Jamaah $^{12}$.

Golongan umara' turut memainkan peranan yang penting dengan memberikan naungan dan memperlihatkan kekuasaan mereka dengan mendapat masukan dari ulama untuk membatasi dan menghalangi penyebaran paham, pemikiran Qadariyah di tanah Melayu. Sebagai contoh ketika masa pemerintahan Iskandar Muda (999-1046 H/ 1591-1636 M) yang memerintah Kerajaan Aceh mengeluarkan maklumat berupa larangan kepada 72 aliran (termasuk di dalamnya paham Qadariyah) yang dianggap menyeleweng dan tidak membenarkan ajaran dan paham tersebut disebarkan. Sungguhpun paham Qadariyah dilarang penyebarannya di tanah Melayu, bukan berarti paham Qadariyah tidak berkembang.

Karenanya, pengaruh pemikiran Islam klasik dalam intelektual Islam Melayu sebelumnya pasti bukan sebatas wacana ${ }^{13}$. Namun, secara ilmiah tetap perlu dipertanyakan apa argumen-argumen yang melandasi relevansi dan Kontinuitas pemikiran Islam klasik itu, seberapa tepat argumen-argumen tersebut, apakah hal itu dapat diterima secara ilmiah atau tidak. Berawal dari latar belakang tersebut, akan dibahas lebih jauh tentang relevansi dan kontinuitas dalam intelektualisme Islam Melayu Nusantara.

\section{Relevansi dan Kontinuitas Pemikiran Islam Klasik}

Kemajemukan internal masyarakat MelayuNusantara dan kecenderungan ke arah konvergensi nasional yang mantap, maka pengem-

\footnotetext{
${ }^{12}$ Ibrahim Abu Bakar, "Islamic Modernism in Malay as Reflected in Hadi's Thouht" (McGill University, 1992).

13 Kuntowijoyo, Pengantar Ilmu Sejarah (Yogyakarta: Yayasan Bentang Budaya, 1995), 19.
}

bangan peradaban Islam di Melayu-Nusantara memerlukan pemahaman dan strategi yang tepat. Hal ini akan menghasilkan wawasan intelektualisme terhadap relevansi dan kontinuitas pada masyarakat Melayu, dimana pemahaman dan pengetahuan tentang lingkungan sosial kultural secara keseluruhan. Karena itu harus diperhitungkan bahwa Melayu-Nusantara merupakan suatu negara bangsa yang mempunyai keanekaragaman yang tinggi, baik dari bahasa, suku, kepulauan, dan bahkan agama. Melihat kenyataan ini maka setiap langkah melaksanakan ajaran Islam (dalam hal yang bersifat nasional yang mencakup seluruh rakyat Melayu-Nusantara) di Melayu-Nusantara harus memperhitungkan kondisi sosial budaya untuk menuju kemajuan ${ }^{14}$.

Bangsa Melayu-Nusantara menuju ke arah negara bangsa yang berarti menuju Melayu-Nusantara yang demokratis, egaliter, dan adil. Melayu-Nusantara merupakan negara dengan penduduk yang beranekaragam dan dengan budaya yang bermacam-macam pula. Namun budaya yang bermacam-macam ini ada yang bisa mendukung terwujudnya negara bangsa yang sejalan dengan cita-cita negara tersebut. Hal yang penting untuk dilakukan adalah, budaya yang beranekaragam itu harus mewujud ke arah ke MelayuNusantara an.

Dalam perjalanan sejarah kebangsaan, proses pertumbuhan Ke Melayu-Nusantaraan tidak terbatas pada satu tempat dan dalam satu masa. Sebagaimana sering diungkapkan oleh para pemimpin bangsa bahwa ke Melayu-Nusantaraan mempunyai akar-akar yang jauh dalam sejarah Nusantara.

Dengan memahami manusia dan perilaku dalam perspektif Islam, maka manusia terdiri dari unsur jasmani, rohani, dan nafsani yang menjadikan manusia sebagai

\footnotetext{
${ }^{14}$ Aprizal dan A Yusri, "Relasi Kekuasaan dalam Budaya Melayu Riau," Demokrasi \& Otonomi Daerah 11, no. 2 (2013): 71-80.
} 
makhluk yang sempurna di muka bumi. Manusia memiliki kebebasan dalam memilih perilaku yang baik atau yang buruk, yang benar atau yang salah, oleh karena itu manusia dibekali oleh Allah SWT akal dan hati.

Unsur-unsur yang ada dalam diri manusia membutuhkan tumbuh kembang yang sehat supaya bisa menjalankan fungsi manusia sebagai khalifatul fil ardi dimana dapat menjalankan tugas-tugas kemanusiaan dan peradabannya. Proses tumbuh kembang manusia akan dapat dicapai secara optimal melalui pendidikan yang dapat mengembangkan segala unsur dan potensi yang ada pada dirinya ${ }^{15}$. Pada umumnya Intelektual muslim Indonesia mengemukakan bahwa Islam mampu menjadi sumber etika penyelenggaraan negara dan bagi kehidupan berbangsa dan bernegara di dunia Melayu. Tetapi pendapat yang mengemukakan itu tidak diiringi dengan konsep mengenai bagaiman cara menjadikan Islam sebagai sumber etika tersebut. Sehingga Islam, sebagai satu-satunya agama pemilik petunjuk yang benar dan sempurna belum mampu menunjukkan fungsi dan kesempurnaannya di (MelayuNusantara) Indonesia. Bersama dengan itu bangsa Indonesia yang mayoritas beragama Islam, serta selalu mengakui sebagai umat terbaik dari seluruh umat manusia, juga belum mampu menunjukkan predikat terbaiknya itu di Indonesia.

Tidak berfungsi ajaran Islam dan identitas kemelayuannya di Indonesia sebagaimana mestinya, telah melahirkan bangsa yang berperilaku rancu. Bangsa Indonesia selalu mengaku bangsa yang selalu agamis dan taat ${ }^{16}$. Namun perilakunya tidak menampakkan hal itu. Demikian pula, bangsa Indonesia mengaku sebagai bangsa yang mayoritas Melayu. Namun perilakunya juga tidak menampakkan hal itu. Kerancuan-kerancuan ini ternyata disebabkan oleh kerancuan juga. Yaitu terputusnya ideologi dari akar pembentuknya yaitu nilai-nilai ajaran Islam. Yang terjadi kemudian adalah, masing-masing Islam dan Melayu, mencari jalannya sendiri-sendiri.

15 Ali Yusri, "Relasi Kekuasaan Dalam Budaya Melayu Riau," Jurnal Demokrasi Dan Otonomi Daerah 11, no. 2 (2013): 71-80.
Islam yang kaya nilai berusaha dioperasionalisasikan tanpa menggunakan alat operasional.

Sebaliknya Melayu yang memiliki alat operasional yang kuat berusaha dioperasionalisasikan dengan kekosongan nilainilai. Akhirnya yang terjadi adalah benturan-benturan berdarah diantara keduanya. benturan-benturan berdara ini akhirnya memutuskan hubungan antara keduanya, dan membuat keduanya samasama kehilangan makna dan sama-sama tidak berfungsi. Terputusnya hubungan kedua inilah yang kini menenggelamkan umat Islam Indonesia dan bangsa Indonesia kedalam berbagai permasalahan, konflik, dan krisis silih berganti tanpa kunjung selesai. Terutama krisis moral. Demikian jauhnya Islam dan identitas Kemelayuan terpisah sehingga umat Islam dan bangsa Indonesia pada umumnya menganggap keduanya tidak memiliki hubungan sama sekali. Ditengah kekosongan pedoman hidup, dimana agama Islam dan kemelayuannya sudah tidak berfungsi untuk membangun dan menata hidup bangsa Indonesia mengadopsi sains-sains atheis dan sistem-sistem atheis Barat secara besarbesaran untuk membangun dan menata hidupnya.

Bangsa yang bertuhan dijelajahi dengan sains-sains yang tidak ada Tuhan di dalamnya, kemudian ditata dengan sistem yang sama sekali tidak memberi tempat bagi Tuhan berpartisipasi di dalamnya. Hasilnya inilah masyarakat yang rancu. Masyarakat antara ucapan dan perbuatan yang tidak ada hubungan sama sekali. Mengaku beragama Islam, mengaku bangsa melayu yang luhur. Tapi perilaku yang dipertontonkan sama sekali tidak menampakkan nilai-nilai Islam maupun kemelayuannya.

Dengan relevannsinya menemukan sumber dari permasalahan ini, mengajukan sebuah konsep besar yang utuh atau lengkap. Tidak hanya dapat menyelesaikan

\footnotetext{
${ }^{16}$ Daniel George Edward Hall, History of South East Asia (Macmillan International Higher
} Education, 1981). 
persoalan pokoknya, tetapi juga mampu membuat umat Islam Indonesia membangun peradaban Islam yang unggul dan mendunia di Indonesia. Caranya adalah dengan mengembalikan kontinuitas kemelayuan kepada akarnya yaitu agama Islam. Dengan terusmenerus melakukan pengisian subtansi nilainilai ajaran Islam ke dalam dunia Melayu lalu menyatukan keduanya menjadi fondasi untuk membangun ilmu-ilmu baru yang Islam dan atau intelektualisme kemelayuannya. Dengan ilmu-ilmu baru itu dibangunlah sistem-sistem penataan masyarakat yang Islami pula. Dengan ilmu dan sistem baru yang Islami itulah pikiran, sikap, dan perilaku masyarakat diisi dengan nilai-nilai Islam. Kemudian masyarakat dibangun dan ditata dengan pikiran, sikap, dan perilaku yang Islam. Dengan demikian barulah akan lahir masyarakat dan peradaban Melayu Islam di Indonesia. Pekerjaan ini adalah pekerjaan yang paling besar dan pihak yang bertanggung jawab atas pekerjaan besar ini adalah umat Islam Indonesia. Sebagai penguasa ajaran Islam umat Islam adalah pihak yang memiliki peluang yang terbesar untuk memenuhi seluruh tahapan kerja besar ini dengan baik.

Tradisi intelektual umumnya mengacu pada proses transmisi keislaman, pembentukan wacana intelektual, yang dalam proses selanjutnya menjadi tradisi yang dikembangkan dan dipelihara secara terus menerus. Tradisi intelektual ini kemudian berwujud pada lahirnya karya-karya keislaman ${ }^{17}$. Kontak keilmuan Islam antara wilayah MelayuNusantara dengan pusat keilmuan di Haramain semakin intensif pada gilirannya, ketika sebagian ulama kembali ke tanah airnya, mereka menjadi lokomotif utama dalam sosialisasi dan transmisi berbagai pemikiran keagamaan ke kalangan masyarakat Muslim Nusantara.

Secara garis besar, pemikiran umat Islam dapat dibagi kepada empat kelompok, yakni: Pertama, bidang ketuhanan, yang meliputi pembahasan mengenai Allah dan sifat-sifatNya dan hubungan alam semesta dengan-Nya.

17 Islan Saputra Nababa, "Konsep Pemikiran dan Jalan Yang Ditawarkan Munawir Sjadzali Dalam
Kedua, bidang akhlak (etika), yang meliputi pembahasan mengenai manusia dan perilakunya; hubungan manusia dengan Tuhan, hubungan manusia dengan sesamanya, hubungan manusia dengan alam semesta. Ketiga, bidang fisika; meliputi pembahasan tantang alam pertumbuhan dan perkembangannya. Keempat, bidang eksakta, yang meliputi pembahasan mengenai keilmuan seperti; matematika, geometri, astronomi dan lain sebagainya. Hasil pemikiran umat Islam tentang ke empat hal tersebut cukup banyak membawa perkembangan terhadap ilmu pengetahuan dan peradaban manusia. Hal ini memiliki nilai yang penting dalam kehidupan manusia. Terkait dengan permasalahan ketuhanan, banyak konsepkonsep pemikiran yang muncul. Hal ini disebabkan ketuhanan merupakan hal mendasar dalam ajaran Islam, persoalannya sangat rumit dan unik.

Modernis terdahulu menekankan rasionalitas dalam usaha menghilangkan praktek-praktek keagamaan tradisional, dan menegaskan bahwa Islam tidak hanya sekedar mengizinkan, tetapi membutuhkan kemodernan. Tentang wacana di MelayuNusantara, diam-diam kemodernan di pertegas dalam istilah teknologi dan ilmu pengetahuan. Karena modernisme sebelumnya menggabungkan rasionalitas teknologi serta ilmu pengetahuan dengan spritualisme Islam, maka persoalan agama dikeluarkan dari wilayah kerja rasionalitas. Ini berarti konsep kaum modernis tentang masyarakat Islam terbatas pada pemahaman literal ajaran sosial dari Alquran dan Hadis.

Dalam keadaan genting ini kehadiran kalam Mu'tazilah menjadi signifikan dalam wacana Melayu-Nusantara. Di kalangan teologi Islam di Melayu-Nusantara, hanya Mu'tazilah yang membedakannya dari mazhab Islam yang lain adalah keutamaan nalar spekulatif (nazar). Bagi Mu'tazilah nalar spekulatif sangat penting untuk mengetahui Tuhan dan memahami keadilannya, dan kemudian mematuhinya.

Permasalahan Dui Pungsi Di Indonesia," Aqidah Jurnal Ilmu Politik Dan Agama 1, no. 1 (2015). 
Terlepas dari cara teologi Mu'tazilah memahami hasil refleksi dan penalaran spekulatif mereka yang posisinya dibawah alkitab sebagai dalil pembuktian. Pendekatan ini, yaitu: Pertama, penalaran spekulatif merupakan usaha yang dilakukan oleh theolog Mu'tazilah untuk memahami persoalan agama. Dengan kata lain nalar spekulatif adalah anti tesis dari peran dogma kitab suci, yang menjadi pendirian Sunni. Kedua, bagaimanapun, karena manusia bukan makhluk yang absolut, maka semua yang mereka hasilkan adalah kondisional. Ketiga, karena itu, kebenaran manusia adalah relatif (zanny) dan temporal. Ketidakpastian ini merupakan kualitas yang esensial dari semua aktifitas intelektual manusia, termasuk penalaran spekulatif.

Melayu-Nusantara membicarakan kemahaadilan Tuhan dalam masalah sosiologis, kebebasan manusia untuk menentukan jalannya perbuatan dan bertanggung jawab atas perbuatan sesuai dengan prinsip keadilan dan kesetaraan sosial ekonomi. Doktrin Islam sosial yang merupakan inti ajaran Mu'tazilah yang fundamental, tantang menyuruh yang baik dan melarang yang jahat, menjadi sebuah bentuk tanggungjawab untuk menghilangkan penderitaan, penyiksaan dan memerintahkan supaya organisasi Muslim bersaing dalam kebaikan, demi dunia yang lebih baik ${ }^{18}$. Kaum Mu'tazilah telah menegaskan bahwa kewajiban etis dan ibadah (taklifi) yang dibebankan oleh Tuhan (al-mukallif) kepada manusia (al-mukaliffun) orang-orang yang menerima kewajiban dari Tuhan, secara inheren adalah baik, karena kewajiban itu memberi manusia dasar untuk patuh kepada Tuhan, dan yang demikian itu untuk mendapatkan pahala di hari akhirat nanti. Pemikir Melayu-Nusantara kontemporer di atas, berlawanan dengan Mu'tazilah, mereka puas untuk hanya mengandalkan kitab suci sebagai dasar untuk mengetahui Tuhan. Namun mereka tetap menggunakan keutamaan akal sebagai alat solusi Islam terhadap persoalan sosial di dunia. Ini merupakan perhatian utama untuk mengembangkan teologi praktis yang bisa memberikan penafsiran Islam bagi realitas sosial dan politik, hal tersebut membedakan rasionalis klasik, yaitu Mu'tazilah, dari teolog modernis di Melayu-Nusantara. Dengan cara ini kelihatan bahwa perbedaan antara teolog Mu'tazilah dan modernis, lebih pada penekanan aspek pengalaman esoteris agama.

\section{SIMPULAN}

Relevansi pemikiran Islam klasik dalam intelektualisme Islam Melayu Nusantara dapat dilihat dalam eksisnya dua organisasi terbesar di Indonesia yaitu Nahdatul Ulama (NU) yang dalam intelektualismenya mengarah pada aliran Jabariyah serta Muhammadiyah yang intelektualismenya mengarah pada Muta'zilah. Kontinyuitas pemikiran Islam klasik dalam intelektualisme Islam Melayu Nusantara memuncukan pemikir modernis MelayuNusantara lebih dekat dengan pendirian historis Mu'tazilah ketimbang dengan pendirian historis tradisionalis.

\section{DAFTAR PUSTAKA}

Aprizal, dan A Yusri. "Relasi Kekuasaan dalam Budaya Melayu Riau." Demokrasi \& Otonomi Daerah 11, no. 2 (2013): 7180.

Ashari, Hasan. Menguak Sejarah Mencari Ibrah: Risalah Sejarah SosialIntelektual Muslim Klasik. Bandung: Citapustaka Media, 2006.

Azhari, Susiknan. "Karakteristik Hubungan Muhammadiyah dan NU dalam Menggunakan Hisab dan Rukyat." AlJami'ah: Journal of Islamic Studies 44, no. 2 (2006): 453-86.

Azra, Azyumardi, dan Oman Fathurrahman. Jaringan Ulama. Diedit oleh Taufik Abdullah. 5 ed. Jakarta: Ichtiar Baru van Hoeve, 2002.

Bakar, Ibrahim Abu. "Islamic Modernism in Malay as Reflected in Hadi's Thouht." McGill University, 1992.

Fathurahman, Oman. "Jaringan ulama: pembaharuan dan rekonsiliasi dalam

\footnotetext{
${ }^{18}$ Ris'an Rusli, "Study of Islamic Thought in Islam Malay Archipelago: Social Studies, Intellectualism and
}

Contextual Cultures," The Journal of Social Sciences Research 5, no. 1 (2019): 543-50. 
tradisi intelektual islam di dunia MelayuIndonesia." Studia Islamika 11, no. 2 (2004).

Fathurrahman, Oman. Tradisi Intelektual Islam Melayu-Indonesia: Adaptasi dan Pembaharuan: Book Review Peter Riddell, Islam and the Malay-Indonesian World. Singapore: Horizon, 2001.

Hall, Daniel George Edward. History of South East Asia. Macmillan International Higher Education, 1981.

Iqbal, Muhammad. "Akar Tradisi Politik Sunni di Indonesia Pada Masa Kerajaan Islam di Nusantara." ISLAMICA: Jurnal Studi Keislaman 6, no. 1 (2011): 51-65.

Kuntowijoyo. Pengantar Ilmu Sejarah. Yogyakarta: Yayasan Bentang Budaya, 1995.

Margono, Hartono. “KH. Hasyim Asy'ari dan Nahdlatul Ulama: Perkembangan Awal dan Kontemporer.' Jurnal Media Akademika 26, no. 3 (2011).

Mudzhar, M Atho. "Masyarakat Indonesia Baru dalam Perspektif Global." Mukaddimah 5, no. 8 (1999).
Munawar-Rachman, Budhy. Kontekstualisasi Doktrin Islam dalam Sejarah. Jakarta: Paramadina, 1995.

Nababa, Islan Saputra. "Konsep Pemikiran dan Jalan Yang Ditawarkan Munawir Sjadzali Dalam Permasalahan Dui Pungsi Di Indonesia." Aqidah Jurnal Ilmu Politik Dan Agama 1, no. 1 (2015).

Rusli, Ris'an. "Study of Islamic Thought in Islam Malay Archipelago: Social Studies, Intellectualism and Contextual Cultures." The Journal of Social Sciences Research 5, no. 1 (2019): 54350.

Sunarto, AS. "Paradigma Nahdlatul 'ulama Terhadap Modernisasi." Jurnal Sosiologi Islam 3, no. 2 (2013).

Yatim, Badri. Sejarah Peradaban Islam Dirasah Islamiyah II. Jakarta: Raja Grafindo Persada, 2010.

Yusri, Ali. "Relasi Kekuasaan Dalam Budaya Melayu Riau." Jurnal Demokrasi Dan Otonomi Daerah 11, no. 2 (2013): 71-80. 